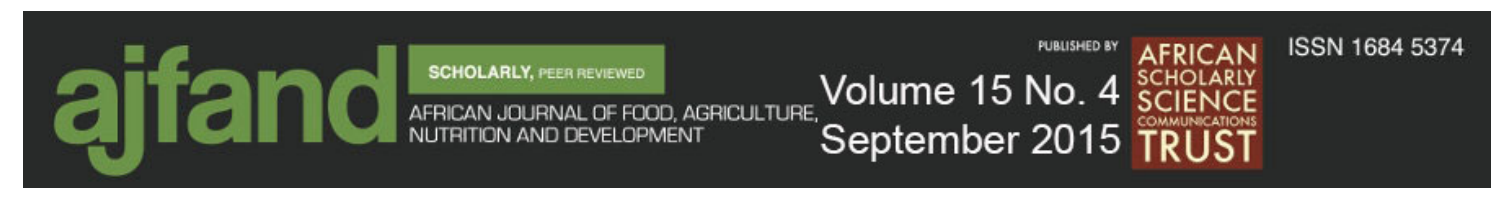

\title{
CREATING SCARCITY FROM ABUNDANCE: BUMPER HARVESTS, HIGH PRICES, AND THE ROLE OF STATE INTERVENTIONS IN ZAMBIAN MAIZE MARKETS
}

\section{Kuteya $\mathrm{AK}^{1 *}$ and NJ Sitko ${ }^{2}$}

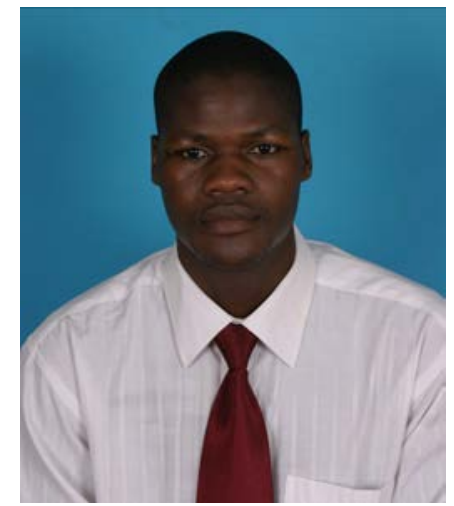

Auckland Kuteya

${ }^{*}$ Corresponding author email: ankuteya@gmail.com

${ }^{1}$ Research Associate II, Indaba Agricultural Policy Research Institute (IAPRI), 26A Middleway Road, PostNet Box 99, Kabulonga, Lusaka, Zambia. Fax: +260 211261199

${ }^{2}$ Assistant Professor, International Development, Department of Agricultural, Food, and Resource Economics, Michigan State University (MSU), and currently on longterm assignment with IAPRI, Lusaka, Zambia. 


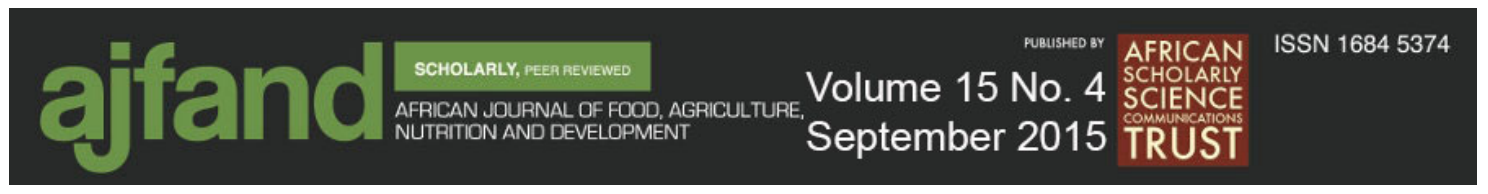

\section{ABSTRACT}

In 2012/13 Zambia experienced a significant spike in maize meal prices, which coincided with three consecutive years (2010 - 2012) of record maize surpluses. This seemingly paradoxical price spike occurred in the wake of a dramatic escalation of the Government's Food Reserve Agency (FRA) interventions in the market, with the FRA purchasing approximately $80 \%$ of the available surplus during these surplus production years. Using a case study approach, this article explores Zambia's maize price spikes amidst years of bumper harvests. The study findings reveal that maize procurement and marketing behavior of the Government through the FRA contributed to major structural changes to the maize market: (1) A withdrawal from the market by commercial mills. By purchasing majority of the maize on the market, the FRA limited the need for commercial mills to access maize directly from the market. This reduced competition in the wholesaling sector and concentrated maize supply chain around the FRA; (2) Rationing of the FRA maize sold at subsidized prices to commercial mills. The FRA depots were unable to consistently meet the demand requirements of the commercial milling sector and as a result, some mills were prioritized in terms of receiving FRA maize. Mills that could not consistently access subsidized maize from the FRA were put at a comparative disadvantage; (3) Exit of the commercial farming sector from maize production. Between 2010 and 2013 commercial maize production in Zambia halved, from 300,000 to less than 150,000 metric tonnes. This was due to the price uncertainty created by FRA subsidies to commercial mills, which are the traditional markets for commercial farmers, as well as significant increase in smallholder production; and (4) Squeezing the informal processing sector out of the market. By procuring the majority of the available surplus and selling it at subsidized rates to a selected group of commercial mills, the informal market, including small-scale traders, retailers, and hammer mills, were limited in their ability to participate in the market. This in turn undermined the market channel most often used by poorer urban and rural households. These structural changes in the organization of Zambia's maize market led to a decline in available maize supplies and reduced levels of private-sector competition making the market vulnerable to unanticipated demand shocks.

Key words: Maize, price spikes, bumper harvests, subsidies, markets, traders, agriculture, Zambia 


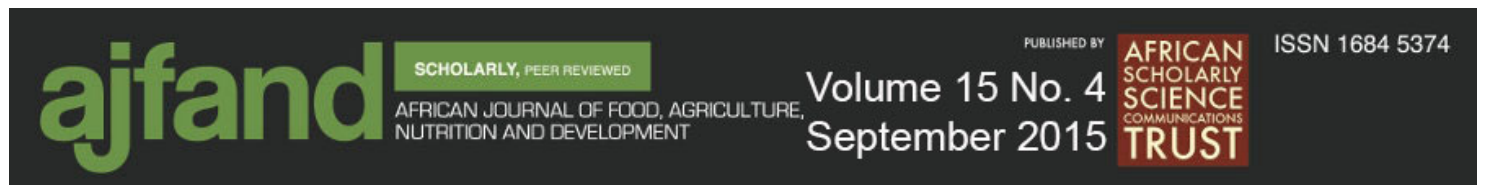

\section{INTRODUCTION}

In November 2012 the Government of Zambia officially confirmed widespread maize meal shortages in the urban industrial centers of Zambia's Copperbelt Province [1]. Throughout the Copperbelt, maize meal prices were rising rapidly, while consumers were forced to queue for hours, sometimes in vain, in an effort to acquire a bag of the nation's staple food. In response to the shortages and price spikes, the government increased the price subsidies it provided on maize sold by the parastatal Food Reserve Agency (FRA) to large-scale maize mills. Despite these efforts and statements by the FRA that it still held over 700,000 metric tons of maize in its storage facilities, maize meal prices continued to rise and stock-outs persisted.

In Lusaka, the capital city, maize meal prices rose by $21 \%$ between November and December of 2012. As a result, maize meal prices in Lusaka were $24.6 \%$ higher in December 2012 than the previous year. In Mwinilunga, an outlying district along the border of the Democratic Republic of Congo, the price rise was even more dramatic. Between November and December 2012, maize meal prices rose by 33\%. This contributed to a $26.9 \%$ increase in the price of maize meal in December over the previous year.

Rapid food price spikes are not new to Zambia [2]. As a landlocked country, with poor infrastructure and dependence on rain-fed agriculture to produce a single staple cereal, Zambia is susceptible to food price spikes and food price volatility [3]. In Zambia food price spikes tend to emerge under a similar set of conditions. In most cases, price spikes in Zambia are triggered by domestic production shocks, mostly due to adverse weather conditions, leading to food supply deficits. The price response to this deficit tends to be worsened by the large wedge between import and export parity prices, resulting from high transport costs and poor market infrastructure. This price wedge limits the capacity of imports from abroad to bring down local food prices [4]. Finally, in many cases, uncertainty over how the government intends to respond to the supply shortfall often leads to delays in private sector imports, which in turn exacerbates the increase in domestic food prices [5].

Yet, the high food prices of 2012/13 diverged in important ways from this common scenario. Rather than emerging from a domestic production shortfall, the food price spike of 2012/13 came in the wake of three consecutive years of record maize surpluses. From 2010 through 2012, Zambian farmers produced a total of 8.6 million metric tonnes of maize [6]. After accounting for the maize retained by producers for their consumption needs, Zambia's total marketed surplus over this period was in the range of 4.6 million metric tonnes, which far exceeded the national maize consumption requirement. Of this surplus, the government purchased approximately $80 \%$ or 3.68 million metric tonnes through the Food Reserve Agency (FRA).

The Food Reserve Agency (FRA) was established in 1996 by the Government of the Republic of Zambia. Its original mandate was to establish and administer a national food reserve [7]. However, after the amendment of the FRA Act in 2005, crop marketing support and maize price setting were also included as additional roles of the Agency [7]. 


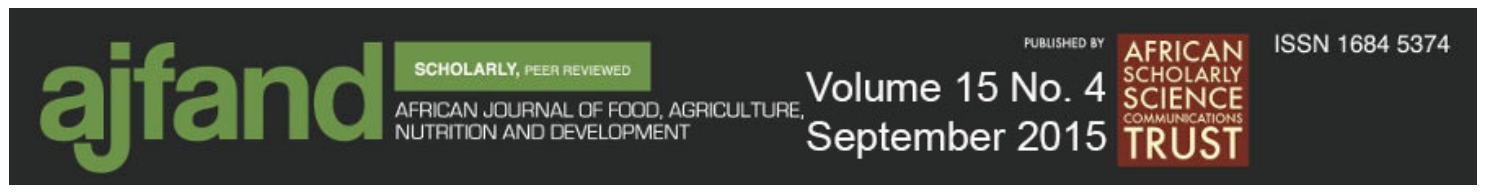

Despite budget allocations that limit FRA purchases to strategic reserve levels of 500,000 metric tons, the FRA is able to borrow from commercial credit markets and expand its market presence to fulfill its market support and price setting mandate.

What explains the widespread maize meal shortages and high maize meal prices in Zambia despite record levels of surplus maize production? Identifying answers to this question is critical, as unanticipated food price spikes can lead to net welfare losses, both in terms of economic growth rates and household food and nutrition security $[8,9]$. In Zambia, the popular explanation for the 2012/13 food price spikes focused on the structural limitations of the private sector, including insufficient commercial maize processing capacity in low density regions, and rent seeking behaviors by large-scale milling firms, maize meal retailers, and those involved in the informal trade of maize across Zambia's long and porous borders [1]. Yet, given three years of record maize production, coupled with large state held maize stocks, the emergence of grain shortages and high maize meal prices likely has more fundamental causes, rooted in distortions of the Zambian maize market arising from excessive intervention by the public sector in its operations.

This paper seeks to identify and analyze the causes and consequences of the paradoxical food price spike of 2012/13. The authors argue that the maize procurement and marketing behaviors of the FRA from 2010 to 2012 contributed to a structural reorganization of Zambia's maize marketing and processing sectors. The authors explore this market restructuring in terms of the two predominate private market channels that operate in Zambia: 1) the formal market, which is characterized by large volume, commercial maize processing and marketing firms linked to both commercial and small-scale producers; and 2) the informal market, which is characterized by myriad low-volume small-scale traders, small-scale processors, and informal grain retailers. This analysis will show that an expansion of FRA's activities in the maize markets have undermined the competitiveness of these two private market channels in ways that left the maize market more vulnerable to supply and demand shocks than would otherwise have been the case. Though present in earlier years, this vulnerability was exposed in 2012 when increased demand pressure from the region was placed on Zambia's surpluses. Regional demand pressure was increased as a result of South Africa redirecting its maize surplus away from its traditional markets in sub-Saharan Africa and toward Mexico, which experienced a catastrophic crop failure in 2011/12 as a result of a drought. By directing over a million tonnes of surplus to Mexico, regional prices increased and demand pressure shifted toward Zambia, through both formal and informal trade. Because maize markets in Zambia are highly integrated with regional markets through informal and formal trade, rapid increases in regional prices quickly drove up domestic maize prices and exposed the weaknesses in Zambia's domestic market caused by the concentration of surpluses in the hands of the FRA. 


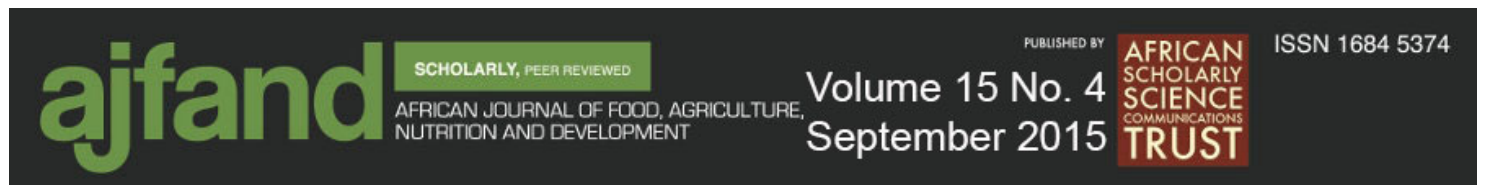

\section{DATA AND METHODS}

This paper utilizes a qualitative approach to analyze the causes and consequences of the reorganization of Zambia's maize markets. A qualitative approach was chosen for this study in order to explore in an in-depth way the institutional changes and dynamics that underpinned the rise in food prices in 2012.

To assess the views of the private sector on the food price spike, semi-structured interviews with various actors in both the formal and informal maize markets were carried out in Zambia. These interviews were conducted from April through June 2013. These included: ten large scale milling firms, six large-scale grain trading firms; five small-scale grain traders; 18 hammer mills; and 28 small-scale grain retailers. Several of these trading firms are multinational and also provided information on trends in regional maize trading. These interview data are complemented by wholesale maize grain price data from the Agricultural Marketing Information Centre (AMIC). The retail breakfast and roller meal prices and the consumer price index (CPI) were collected from the Central Statistical Office (CSO) of the Republic of Zambia.

Production data came from the Ministry of Agriculture and Livestock's (MAL) Crop Forecast Survey (CFS), which provides data on smallholder and commercial farm crop production. Formal trade data in Zambia came from the CSO external trade data section. To examine South African maize grain export trends in Africa and overseas, data from South African Grain Information Service (SAGIS) were used.

The findings were validated during a presentation of research results at a conference held in August 2013 in Lusaka. The FRA was in attendance at this conference and used the opportunity of their attendance to elicit their views on the findings and to provide feedback. This feedback was then incorporated into the analysis.

\section{RESULTS}

\section{Understanding the Shifting Roles of the State and Private Sector in Zambia's Maize Market}

Since the initiation of market liberalization in 1991, the Government of Zambia has maintained an active role in domestic maize markets. However, two distinct regimes of state intervention in maize markets are apparent. The first regime, which began with the inception of the FRA in 1996 and continued to 2009 is characterized by the FRA playing a minority role in the domestic maize market. In all but one election year (2006) during this period the FRA purchased less than half of the available marketed maize, thus enabling significant private participation in the market. The second regime, which began in the wake of the record harvest of 2009/10, is characterized by a high level of activity in the maize market by the FRA, with on average $80 \%$ of the available maize being procured by the FRA. Under this regime, little of the total surplus was available for private sector procurement.

According to representatives of the FRA, the transition to this second regime following the bumper harvest of 2009/10 was necessitated by an inability of the private sector to 
absorb the large surpluses produced in that year and fears of a producer price collapse. To facilitate this expansion the FRA borrowed approximately US $\$ 420$ million from commercial banks to augment funds provided by the Treasury [10]. Yet, the charge of limited private sector capacity is hotly refuted by private grain traders, who claim that private financing and storage capacity was sufficient to handle the increase in surplus. They contend that the decision to expand the role of FRA was primarily a political one, motivated by the impending national elections in 2012 .

Regardless of the motivation for FRA expansion, the shift from the pre-2010 FRA regime to the post-2010 regime caused a significant reorganization of Zambia's maize market. Below we detail the key dimensions of this reorganization.

\section{The Organization of Zambia's maize market before 2010}

Figure 1 presents a schematic representation of the trading relationships between market actors in Zambia's maize market under the first FRA regime. The size of the arrow in the figure indicates relative volume. The vertical middle dashed line separates the formal and informal market channels while the dashed arrows indicate relationships that are seasonal in nature. On the right hand side is the formal maize market. This market linked commercial and small-scale farmers, as well as international suppliers, to formal grain wholesalers, processors, and supermarket retailers. Through links to international and local credit markets, this sector tends to be well capitalized and capable of conducting large volume transactions. According to interviews with commercial grain processors, the Zambian commercial maize processing sector absorbs roughly $60-80 \%$ of the available maize surplus during a normal production year.

On the left side, what we refer as the "informal" market is composed of myriad smallscale traders, wholesalers, retailers, and processors (hammer mills). This sector is critical for poorer consumers and served as an important source of competition to the formal sector.

As shown by thin arrows leading into the FRA, its role in maize market, relative to the private sector, was small under the first regime. Moreover, its engagement with the informal sector was negligible. 

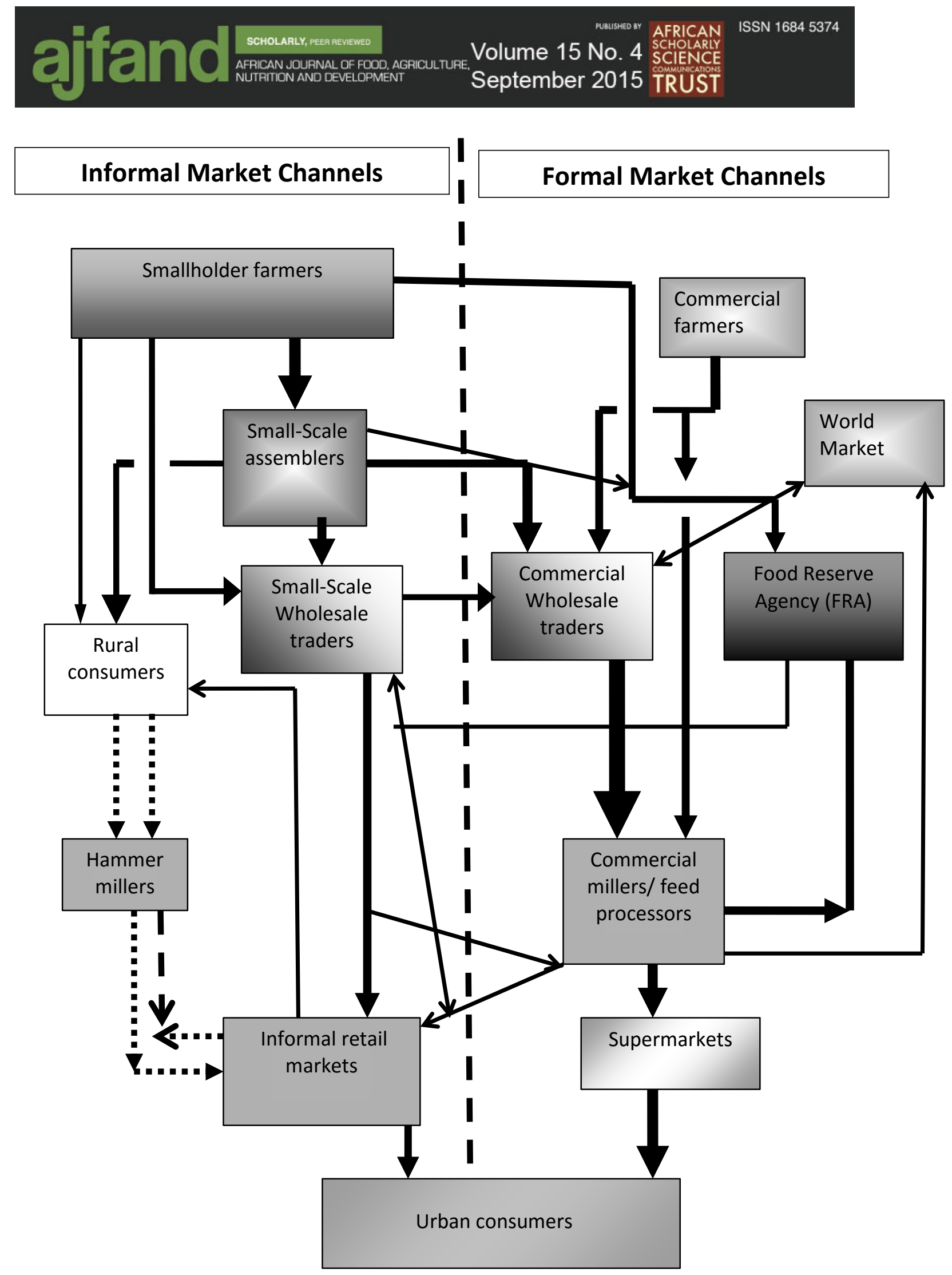

Figure 1: Maize Market Structure Prior to 2010 
As shown in Figure 2, the market structure that developed under the first FRA regime proved largely beneficial to Zambian consumers. As a result of increased competition from formal and informal traders and processors the cost of processed maize meal has declined substantially in real terms since market liberalization in the early 1990s. This decline has been driven largely by declining margins between wholesale grain and retail maize meal prices [11].

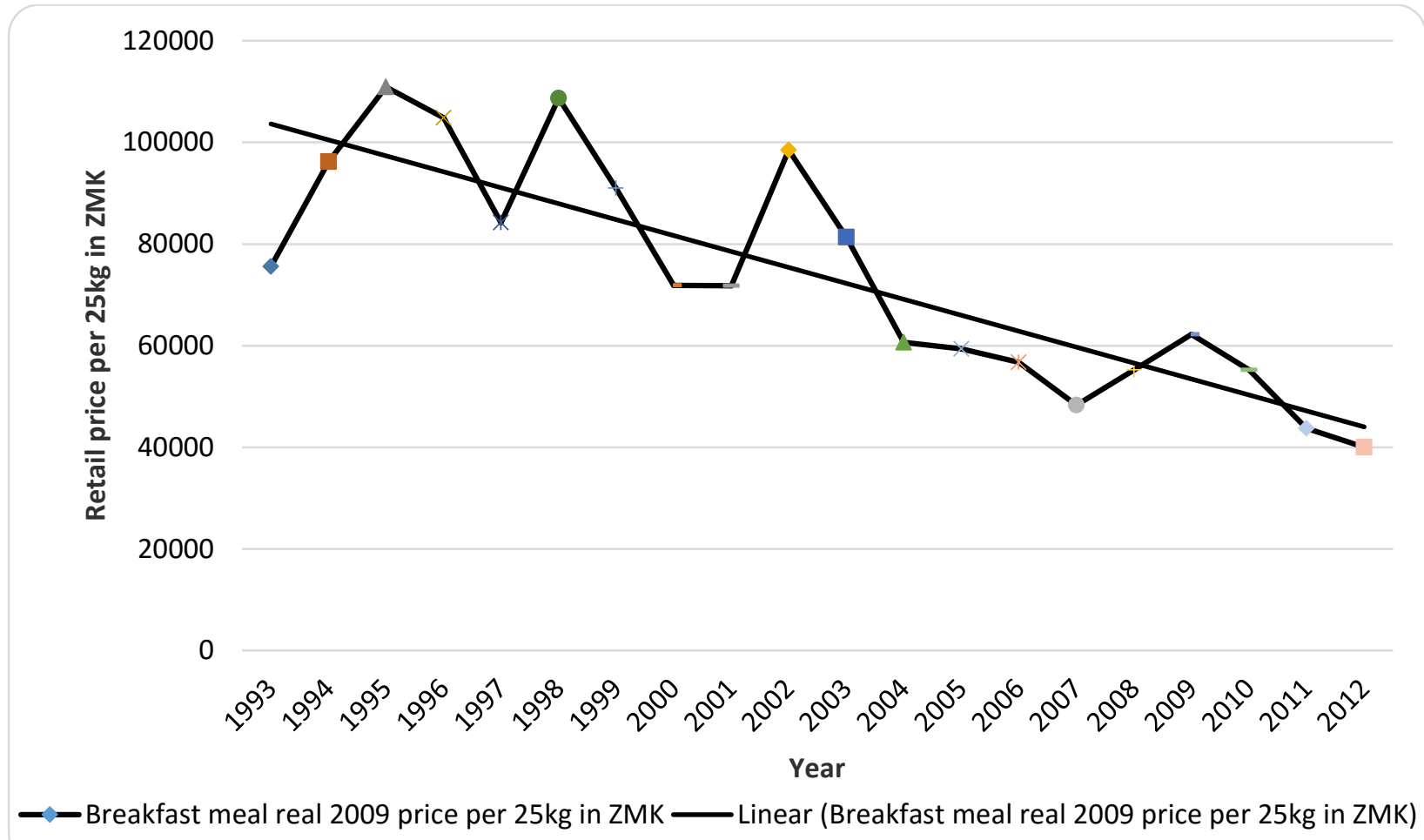

Figure 2: Average Real Annual Maize Meal Price Trends (1993-2010) (Constant 2009 ZMK)

\section{Reorganization of the Formal Maize Market Post-2010}

The transition of the FRA from a minority to majority actor in Zambia's maize market sparked substantial reorganization of Zambia's formal maize market. Many of these changes were detrimental to the market's competitiveness and responsiveness. Drawing on interviews with representative from commercial maize milling, farming, and trading firms, three important changes in the formal maize market are identified as a result of the shift from FRA regime 1 to regime 2.

The first major reorganization of the market was the lack of maize circulating in formal private sector channels. Through the above-market, pan-territorial prices and expansion of available buying depots in rural areas by the FRA, formal private actors were unable to access smallholder maize. The consolidation of the maize market by the FRA had several important effects on the market:

a) It placed a huge burden on public storage systems, leading to significant maize spoilage, estimated at $32 \%$ by the MAL [10]. In contrast, formal wholesalers 
interviewed for this study estimate their storage losses to be in the range of 3 to $5 \%$;

b) Investment in small-scale grain aggregation, which prior to 2010 played a critical role in the market by assembling small quantities of grain directly from farmers [12], was undermined by the private sector's withdrawal from the market, making it difficult for farmers with only minimal surpluses to effectively engage in the market and;

c) The number of available points where grain processors could purchase maize was limited to FRA sheds and the few silos where limited private sector stocks were kept. This, according to respondents, created major distribution bottlenecks in the formal maize market, as the majority of maize demands from the formal processing sector had to be met from FRA sheds. At the same time this introduced scarcities in the wholesale maize markets, leading to higher prices than would have been the case if maize were flowing more smoothly through the market.

The second cause of market reorganization was that certain politically well positioned mills were given preferential treatment in terms of access to FRA maize. Mills that were unable to ensure a steady supply of maize from FRA were forced to either limit their overall throughput to match available FRA supplies, close down temporarily until stocks were again available, or procure grain from private wholesale markets, where prices were significantly higher than the subsidized prices offered by the FRA. In each case the end result was a decrease in competition within the milling sector.

As shown in Figure 3, when the FRA decreased its selling price to commercial mills to 400 ZMK/kg (roughly US\$ 0.08/kg) from September 2011 to August 2012, the retail maize price did not respond [13]. This is because many mills were not able to access the maize at this price or in sufficient quantities to satisfy market demand. In Figure 3, A represents the pre-FRA subsidy period. Point $B$ represents the period during the FRA subsidy while point $\mathrm{C}$ represents post-FRA subsidy period. 

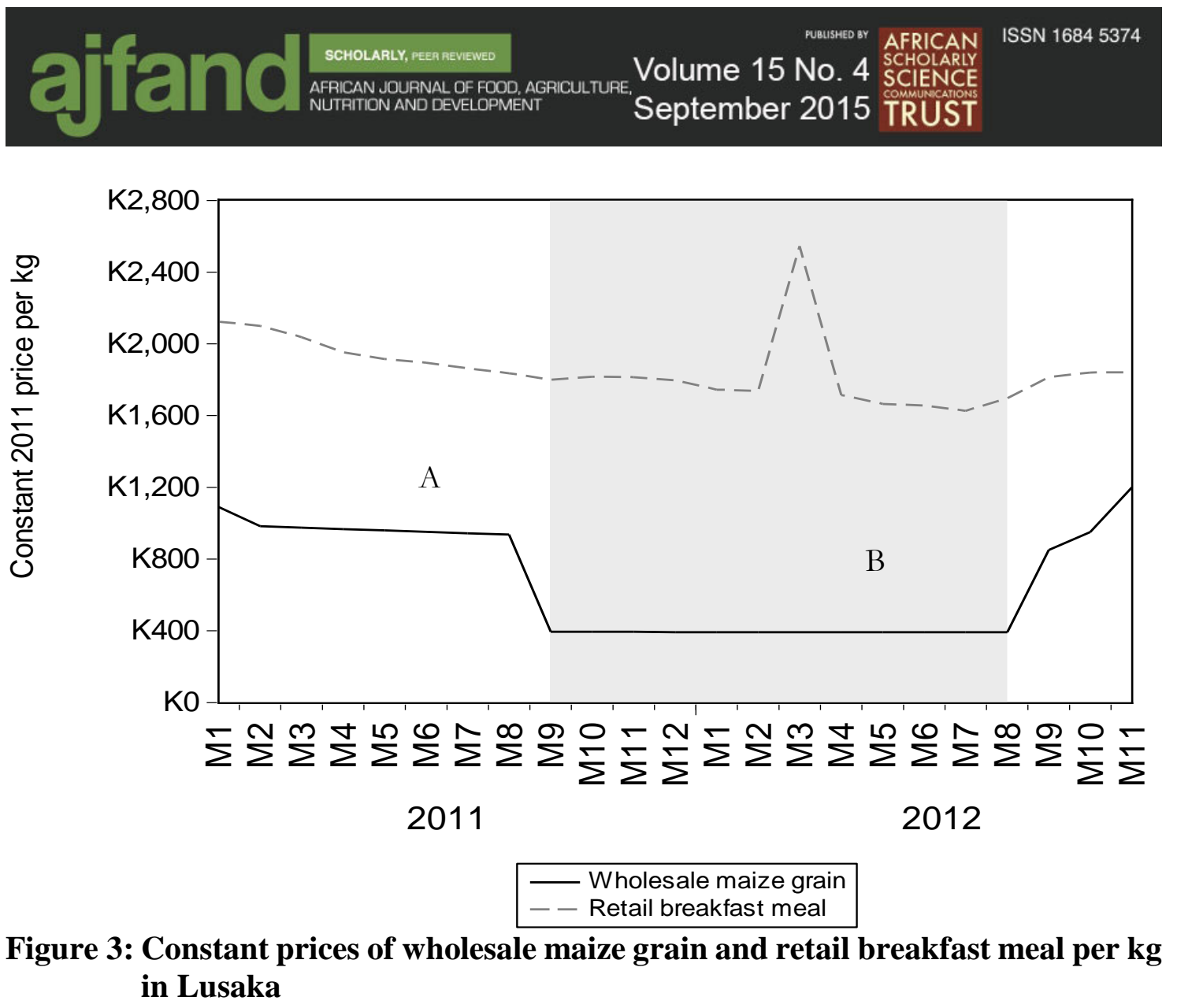

The final major structural change resulting from FRA's activities in the market occurred in the commercial farming sector. Interviews with commercial farmers in Zambia suggest that because of FRA's selling price to commercial mills, many mills began to back away from the standard practice of managing maize supplies through forward contracts with commercial farms. Due to the loss of forward production contracts and general price uncertain for maize caused by FRA subsidies to commercial mills, commercial farmers began to shift away from maize into soya beans production. Thus, commercial maize production halved, from 300,000 metric tonnes to less than 150,000 metric tonnes, between 2010 and 2013. Importantly, commercial farmers are able to irrigate their maize crop if rainfall conditions are poor. Thus, without the buffer of commercially produced maize to compensate for any smallholder supply shortfalls, Zambia's maize market is exposed to greater level of weather-induced supply risk than would otherwise be the case.

\section{The Reorganization of the Informal Maize Marketing and Processing Sector Post-} 2010

According to interviews with small-scale retailers and traders in urban markets in Lusaka, in the years leading up to the 2010 FRA expansion, small-scale traders provided informal retailers with access to relatively low cost maize that was assembled directly from small-scale farmers. This served as an important source of competition for the formal maize milling sector, and contributed to the lower observed margins between wholesale maize grain and retail maize meal prices in Zambia (Figure 4) 

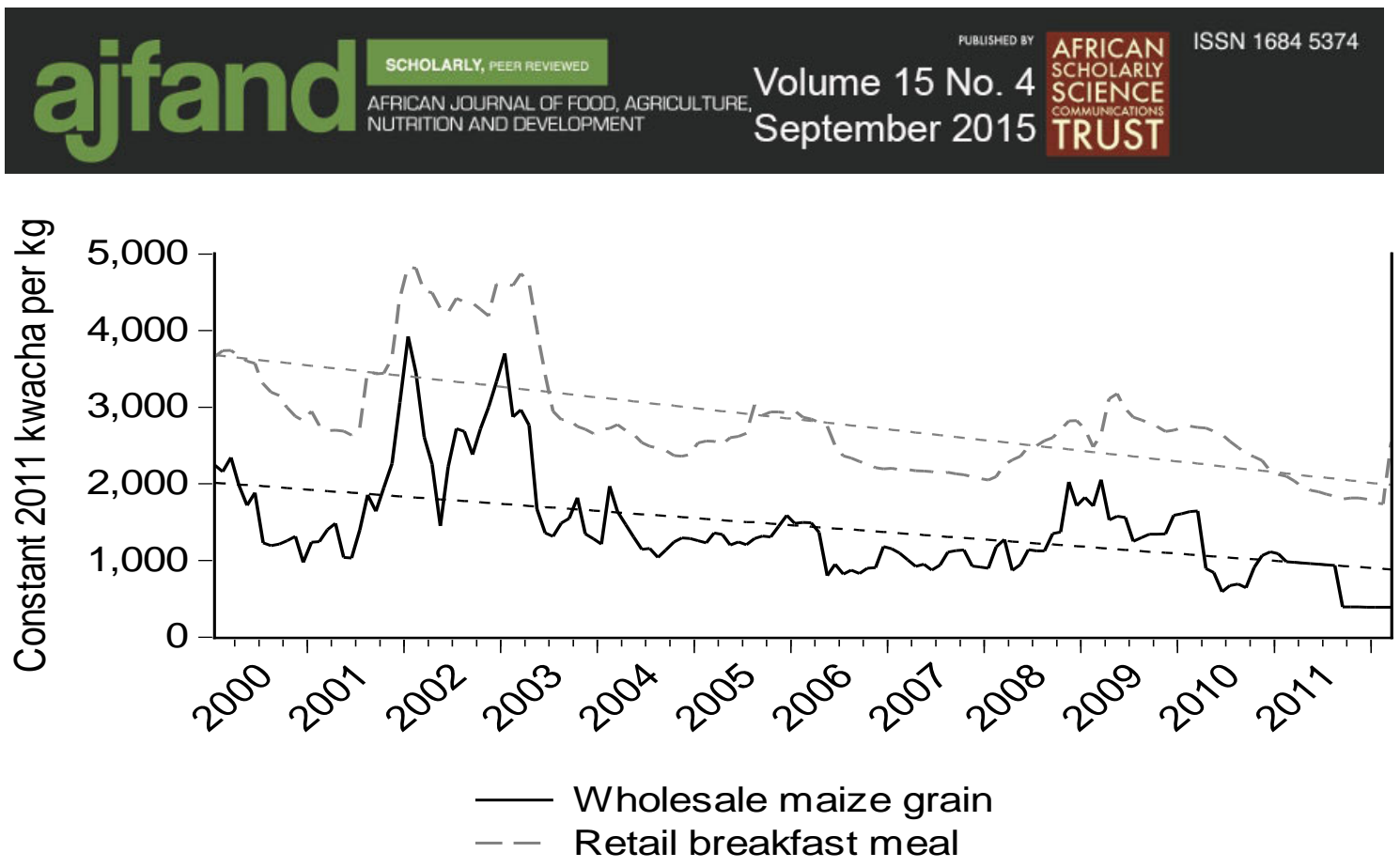

Figure 4: Shrinking market margins over time in Lusaka

However, according to interviews with participants in these critical informal markets, the normal functioning of this sector was negatively affected by the large and unpredictable intervention of the FRA in the maize market between 2010 and 2012. The FRA's interventions disrupted the informal sector by limiting available surplus to be purchased by the small-scale grain assembly sector. Based on farm-gate sales data collected from Zambia's Crop Forecast Survey, the percent of farmers selling grain directly to the private sector, predominantly the small-scale trading sector, declined from $70.1 \%$ in 2008 to $50.3 \%$ in 2011 [12], thus depriving this market of the maize it needed to remain operational. Without maize circulating within informal markets, small-scale maize processors saw a sharp decline in the number of customers bringing maize to be ground into maize meal. By disrupting the informal trading and processing sectors, competition in Zambia’s maize market was decreased.

\section{The Post-2010 Market Structure}

Figure 5 summarizes the effects of FRA's transition to the second buying regime on the structure of Zambia's maize market. The size of the arrow indicates relative volume. As indicated by the thickness of the arrows, this new market structure is highly skewed toward market relationships involving the FRA. Under this new market structure, private sector grain assembly and wholesaling are thinly traded, despite record maize harvests. Commercial production has declined, at the same time that trading relationships between commercial farms and milling firms have deteriorated. Under these conditions, commercial maize mills now access the vast majority of their maize demand through the FRA, rather than primarily through the private sector. As a result of the thinly traded informal market channels, urban and rural consumers become increasingly dependent on access to maize meal produced by commercial mills.

With the number of private market actors and the volume of maize held by the private sector highly constrained, Zambia's maize market became exposed to significant supply risks resulting from bottlenecks between commercial processors and the FRA. Indeed, 


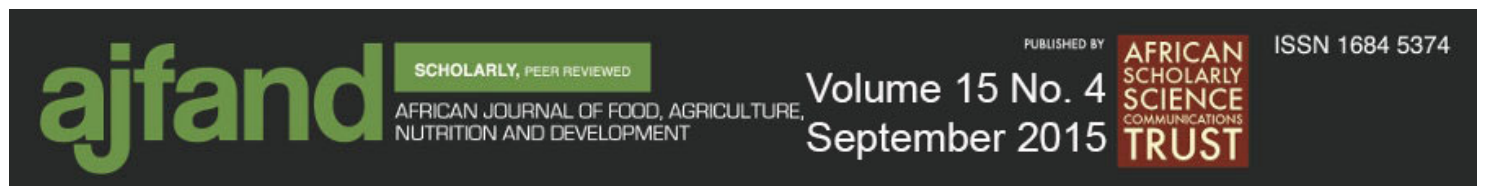

under this market structure the aggregate supplies held by FRA became less important for meeting the demand requirements of consumers than supply bottlenecks between the FRA and the processing sector. This skewed market structure helps to explain how high food prices could emerge in the context of seemingly abundant supplies. 

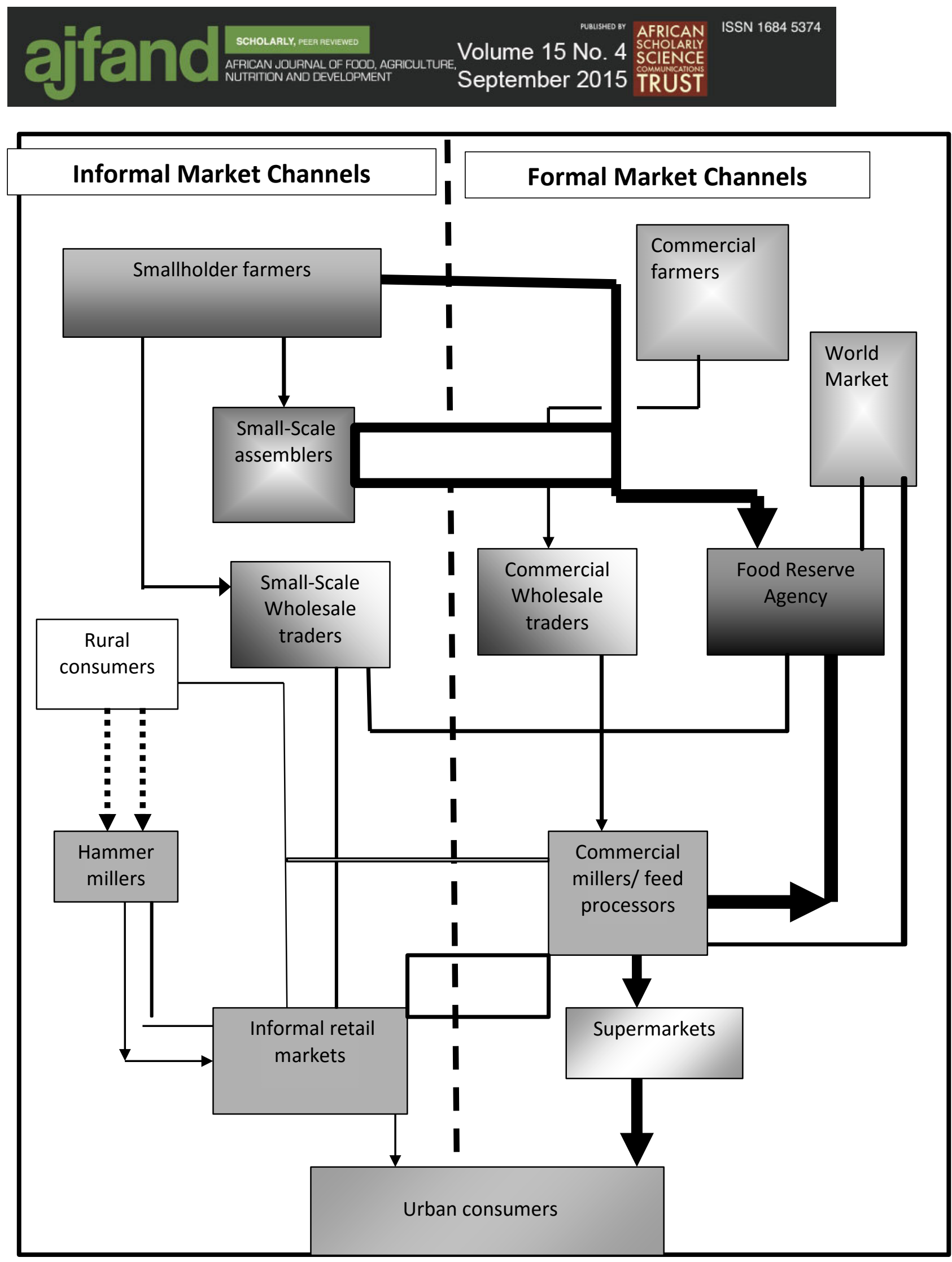

Figure 5: Post-2010 Maize Market Structure in Zambia 


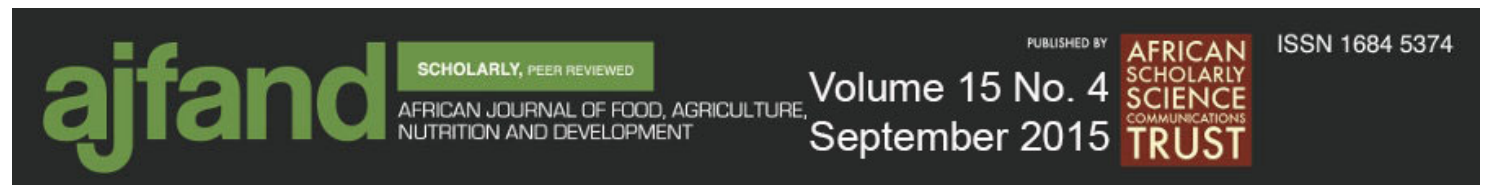

\section{DISCUSSION}

The negative effects of the FRA's shift in market scale on the competitiveness and responsiveness of Zambia's maize market were dramatically exposed in 2011 by the reorientation of South African maize exports away from the southern and eastern African region. As the only consistent exporter of white maize on the continent, South African exports of white maize are critical for moderating prices in the region. As shown in Figure 6, prior to 2010, South Africa would typically export over $90 \%$ of its available surplus to countries in sub-Saharan Africa. However, in 2011 South Africa exported only about $20 \%$ of its available white maize to sub-Saharan Africa.

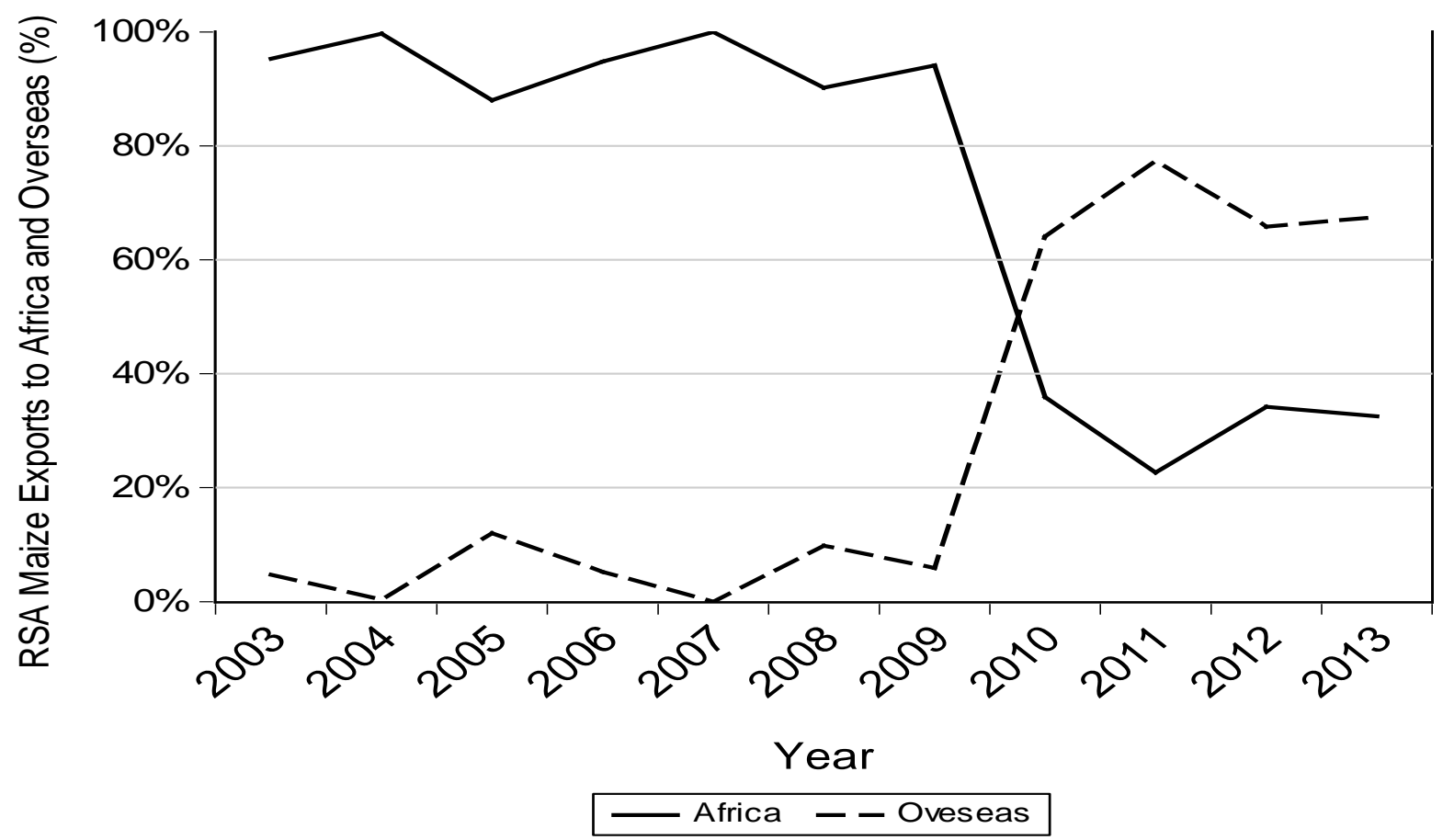

Figure 6: Trends of South Africa's Maize Grain Exports to Africa and Overseas

There are a number of reasons underpinning the strategic redirection of maize surpluses. The first is that world maize prices have been consistently high since 2010, in part due to major crop losses in the Western Hemisphere. Indeed, during the 2011 and 2012 cropping seasons, Mexico imported nearly 2 million metric tonnes of maize from South Africa, or roughly 65\% of South Africa's exports. Second, the emergence of Zambia, and to a lesser extent Malawi and Tanzania, as surplus producers has led South Africa exporters to reconsider the long-term viability of a sub-Saharan Africa-focused export strategy [14]. In particular, South African maize exporters question their capacity to effectively compete in the long-term with emergent exporting nations that enjoy a significant level of producer and marketing support for maize from national governments. Finally, South Africa is a major producer of GMO white maize, which faces a number of import restrictions in the region.

The rapid redirection of maize away from sub-Saharan markets by South African exporters likely placed an unanticipated demand burden on Zambia's maize market, 
particularly from major deficit countries of Zimbabwe and Democratic Republic of Congo. With both private formal and informal markets in Zambia severely hampered by a lack of available grain, these markets were not able to respond to this demand effectively. At the same time, the large amounts of grain held in FRA depots and sheds could not be off-loaded to the market fast enough to moderate escalating prices and dwindling supplies, particularly along Zambia's borders. As a result, Zambia experienced a significant rise in prices despite surpluses of over 700,000 metric tonnes of maize held by the FRA.

\section{CONCLUSION}

Given the market factors affecting South African exports of white maize, preference for overseas markets is likely to continue in future. Sub-Saharan Africa will, therefore, need to become more reliant on emergent African breadbaskets, such as Zambia, to feed its rapidly growing and urbanizing populations.

Political pressure to support food producers in the event of major supply gluts is certainly understandable. Yet, this can quickly spiral out of control, leading to lasting and severe damage to the functioning of the entire maize market. Reactive responses to food supply changes can divert much needed funding away from public goods, such as investment in infrastructure, which in turn stymies the future development of the agricultural sector, leading to a vicious cycle of continued justification for state interventions in food markets [3].

One important lesson from this case study is that maize markets in Zambia are highly responsive to policy incentives. The speed at which actors can move in and out of the market is astounding. This flexibility can be harnessed to achieve the sorts of beneficial outcomes desired by policy-makers. Through institutional reforms to the FRA, increased incentives for private investment in maize markets, and investments in public goods, including infrastructure and social safety nets, Zambian policy-makers can help to reorganize the structure of national and regional maize markets to benefit producers and consumers. This in turn can better position Zambia to serve as the region's breadbasket.

\section{RECOMMENDATIONS}

According to our findings in this paper, we suggest the following interventions:

First, for emerging breadbaskets in the sub-Saharan Africa, as is the case for Zambia, there is need for sufficient producer incentives to enable improvements in overall productivity and production to feed its rapidly growing and urbanizing populations. This in turn requires the development of competitive and efficient output markets for food. If output markets for staple foods are stymied by high levels of government intervention, improvements in production may not translate into improvements in food prices and availability.

Second, there is need to put systems and institutions in place to limit reactive, unpredictable government responses to changes in food supply conditions as reactive 


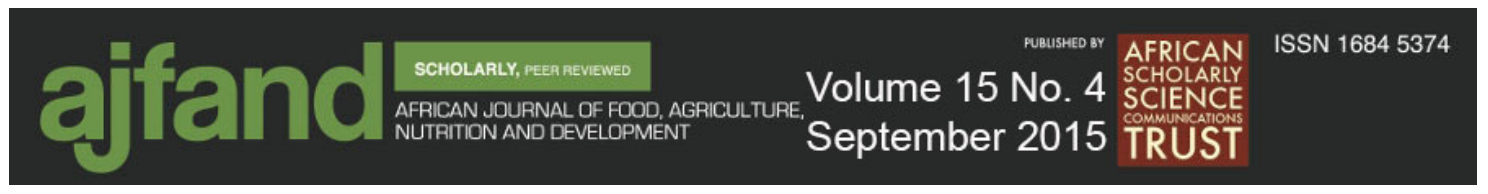

responses to food supply changes have potential to divert the country's limited resources away from investments in public goods like infrastructure development.

Third, the analysis suggests the need for a critical rethinking in management of food prices in Zambia. Refocusing efforts on managing price instability through investments in long-run market developments rather than short-term efforts to stabilize prices may be in the best interest of domestic and regional consumers and producers $[3,15]$. This comes down to making sustained public investments in known drivers of economic growth and poverty reduction, including investments in agricultural research, extension, roads, and education $[16,17]$. These public investments must be coupled with a policy environment that creates incentives for private sector investment.

Finally, this analysis has shown the importance of promoting competition within the formal and informal maize markets. Competition in maize market requires the development of a predictable set of rules and regulations regarding government's behavior. Enhancing this predictability will require weakening the capacity of political actors to direct the FRA. One possibility is locating the FRA within the Central Bank or creating a council drawn from the private and public sector to guide its actions. Through this enhanced predictability, incentives will be created for private sector to invest in grain production, grain procurement and grain storage. As the study has shown, this can provide tangible benefits to local and regional producers and consumers. Moreover, with demand growth in the region, these investments should provide increased incentives for producers to enhance maize output [18]. The budgetary space created by operating a smaller strategic reserve can then be redirected, in part, to supporting poor net food purchasers, through social safety nets such as cash transfers or "food for work" arrangements [3]. 


\section{REFERENCES}

1. Zambia Post Newspaper. Copperbelt Mealie Meal Shortage Worsens. Lusaka, November 22, 2012. Available on: http://www.postzambia.com/postread_article.php?articleId=29689\&highlight= maize\%20shortage. Accessed on 15 ${ }^{\text {th }}$ July 2013.

2. Jayne TS, Zulu B and JJ Nijhoff Stabilizing Food Markets in Eastern and Southern Africa. Food Policy 2006; 31 (4): 328-341.

3. Byerlee D, Jayne TS and RJ Myers Managing Food Price Risks and Instability in a Liberalizing Market Environment: Overview and Policy Options. Food Policy 2006; 31 (4): 275-287.

4. Hazell P, Sheilds G and D Sheilds The Nature and Extent of Domestic Sources of Food Price Stability and Risk. In Managing Food Price Instability in Low Income Countries Workshop. Washington, DC, 2005.

5. Nijhoff JJ, Jayne TS, Mwiinga B and J Shaffer Markets Need Predictable Government Actions to Function Effectively: The Case of Importing Maize in Times of Deficit. Policy Synthesis 6. 2002.

6. Government of Zambia, Central Statistical Office. Crop Forecast Survey Data. CSO, Lusaka, 2010 - 2012.

7. Government of Zambia. Act No. 20 of 2005: An Act to Amend the Food Reserve Act. 2005. Available at:

http://www.parliament.gov.zm/index.php?option=com_docman\&task=docdown load\&gid=543. Accessed on $19^{\text {th }}$ July 2013.

8. Barrett $\mathbf{C B}$ and MF Bellemare Why Food Price Volatility doesn't Matter. Foreign Affairs 12. 2011.

9. Myers RJ On the Costs of Food Price Fluctuations in Low-income Countries. Food Policy 2006; 31 (4): 288-301.

10. Government of Zambia, Ministry of Agriculture and Livestock. Ministerial Statement by the Minister of Agriculture and Livestock on the Farmer Input Support Programme and the Food Reserve Agency. Lusaka, 2013.

11. Chapoto A and TS Jayne Trends in Breakfast Meal and Maize Marketing Margins in Zambia. Food Security Research Project Policy Synthesis 14. Lusaka, 2006. Available on: http://fsg.afre.msu.edu/zambia/ps14.pdf. Accessed on $20^{\text {th }}$ July 2013. 


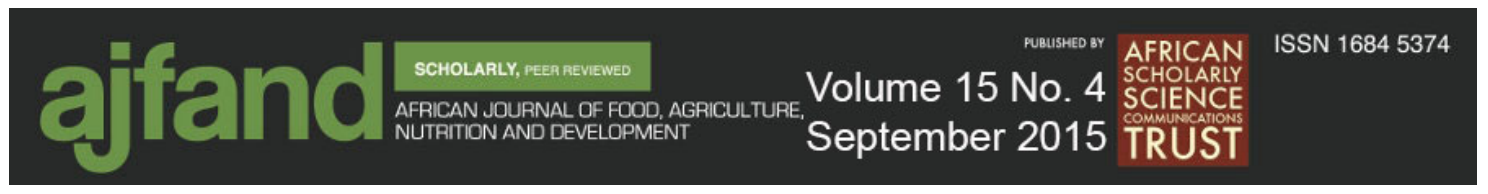

12. Chapoto A and TS Jayne Zambian Farmers’ Access to Maize Markets. Food Security Research Project Policy Working Paper 57. Lusaka, 2011. Available on: http://www.aec.msu.edu/agecon/fs2/zambia/index.htm Accessed on 25 $5^{\text {th }}$ July 2013.

13. Kuteya AN and TS Jayne Is the Government of Zambia's Subsidy to Maize Millers Benefiting Consumers? IAPRI Working Paper 67. Lusaka, 2012. Available on: http://fsg.afre.msu.edu/zambia/wp67.pdf. Accessed on $10^{\text {th }}$ July 2013.

14. Republic of South Africa. Strategic Plan 2012/13-2016/17 for the Department of Agriculture, Forest, and Fisheries. Pretoria, 2013. Found online at: http://www.nda.agric.za/doaDev/topMenu/StratPlan201213-201617.pdf. Accessed on $18^{\text {th }}$ July 2013.

15. Gabre-Madhin E Getting Markets Right. "Managing Food Price Risk and Instability Workshop.” World Bank, 2005.

16. Fan S, Hazell P and S Thorat Government Spending, Growth and Poverty in Rural India. Am. J. Agric. Econ. 2000; 82 (4): 1038-1051.

17. Fan S, Zhang $\mathbf{X}$ and $\mathbf{N}$ Rao Public Expenditure, Growth and Poverty Reduction in Rural Uganda. IFPRI Discussion Paper 4. Washington, DC, 2004.

18. Moyo $\mathbf{S}$ and $\mathbf{H}$ Binswanger Recovery and Growth of Zimbabwe Agriculture. Draft Report prepared for the World Bank, 2012. 